\title{
School meals and the nutrition of schoolchildren
}

\author{
JUDITH COOK, D. G. ALTMAN, ANN JACOBY, AND W. W. HOLLAND \\ Department of Community Medicine, St Thomas's Hospital Medical School, London
}

A. ELLIOTT

Formerly a member of Kent County Council

\begin{abstract}
Cook, J., Altman, D. G., Jacoby, A., Holland, W. W., and Elliott, A. (1975). British Journal of Preventive and Social Medicine, 29, 182-189, School meals and the nutrition of schoolchildren. The contribution of school meals to the nutrition of 778 primary and secondary schoolchildren attending schools in Kent was assessed using information collected during a survey made in 1968-70 which included a weighed diet record, a socioeconomic questionnaire, and a medical examination. Younger children, those from larger families, those without fathers, and those whose mothers worked were more likely to take school meals. Significantly more children from lower social classes and without fathers received them free. School meals made an important contribution to the nutrition of schoolchildren. Children who took them had higher weekday lunchtime nutrient intake during term-time. Children in lower social classes, larger families, and without fathers who took school meals obtained a higher proportion of their weekday intake of nutrients from lunchtime than other children. This applied in particular to nutrients important for growth. School meals consumed by children in the study broadly met the standard set by the Department of Education and Science. The mean energy and protein content of school meals consumed in the study was slightly lower and the mean fat content higher than the standard set for the meal. The mean sugar content was about one-third higher than the suggested amount of sugar to be included in a school meal. There was no evidence that children who took school meals were taller, heavier, had greater skinfold thickness, or were more likely to be assessed as obese than other children.
\end{abstract}

During a study of the nutritional status of schoolchildren in Kent from 1968 to 1970 information on school meals consumption, including weighed records of school meals eaten, was collected.

The characteristics of the children who took school meals and the contribution made by school meals to their nutrition are described in this paper. An attempt is also made to relate the nutritional standard of school meals eaten by children in this study to that set by the Department of Education and Science (1966).

\section{Methods}

The study was carried out by this Department in collaboration with Kent County Council and the Department of Health and Social Security.

Altogether 778 children of both sexes aged 8-11 years and 13-15 years attending 93 schools in Kent took part in the study.
Information was obtained for children taking part in the study from a one-week weighed diet record, a socioeconomic questionnaire, and a medical examination. A total of 655 children took part in the study during school term and their diet records included school meals served at all periods of the school year.

In the questionnaire parents were asked to state what type of lunch the child normally took in term-time and, if they took school meals, whether these were provided free.

Each child in the study kept a detailed diet record for one week. All food and drink consumed during that week was weighed using a modified set of letter balance scales. The description and amount of food consumed was recorded in a diet record book. A special record sheet was provided for recording school meals; details of these were later added to the record book. Children queued as usual 
in cafeteria service or were served as normal at table if service was of the 'family' type. The methods of food recording and of computing the nutrient value of the child's diet have already been described (Topp, Cook, and Elliott, 1972). Any uneaten food was weighed and this was taken into account in the analysis. Thus the nutrient content calculated for the school meals applied to the actual food eaten by children and not the meal as served.

At the medical examination measurements were made of height, weight, and triceps and subscapular skinfold thickness. In addition the nutritional status of the children was assessed by the medical officer using the categories 'obese', 'good', 'fair', and 'poor'. The assessment depended on the observed degree of subcutaneous fatty tissue and muscle bulk.

\section{Uptake of School Meals \\ RESUlts}

About $80 \%$ of children in the study took school meals (Table I). Most of the younger children ate school meals or had lunch at home prepared by their mothers while relatively more older children had packed or other types of lunch. There was a positive association between consumption of school meals and school milk as recorded by younger children. Over one-third took both school meals and school milk (Table II).

Older children from larger families had a significantly higher uptake of school meals than those from smaller families (Table III). In the case of younger children family size was not related to the uptake of school meals. Children whose mothers worked had school meals more often than those whose mothers did not work (Table IV). A significantly higher proportion of fatherless children $(89 \%)$ took school meals compared with children with fathers $(76 \% \mathrm{P}<0 \cdot 01)$.
TABLE II

ACTUAL SCHOOL MILK INTAKE BY ACTUAL SCHOOL MEALS INTAKE *(PER WEEK)

\begin{tabular}{|c|c|c|c|c|}
\hline \multirow{2}{*}{$\begin{array}{l}\text { Intakes of } \\
\text { School } \\
\text { Milk }\end{array}$} & \multicolumn{3}{|c|}{ Intakes of School Meals } & \multirow{2}{*}{ Total } \\
\hline & None & $1-4$ & 5 & \\
\hline None & $27(29 \cdot 7) \dagger$ & $12(22 \cdot 6)$ & $19(11 \cdot 3)$ & 58 \\
\hline $1-4$ & $21(23 \cdot 1)$ & $31(58 \cdot 5)$ & $25(14 \cdot 9)$ & 77 \\
\hline 5 & $43(47 \cdot 3)$ & $10(18 \cdot 9)$ & $124(73 \cdot 8)$ & 177 \\
\hline Total & $91(100 \cdot 1)$ & $53(100 \cdot 0)$ & $168(100 \cdot 0)$ & 312 \\
\hline
\end{tabular}

*(Children 8-11 years with term-time records only) $x^{2}=65.9 \quad P<0.001$

†Percentages are given in parentheses

\section{Free SchoOl Meals}

About $20 \%$ of children who normally took school meals received them free of charge and these children were significantly more likely to be from social classes IV and V than from other social classes. A higher proportion of fatherless children were receiving free school meals than children with fathers (Table V).

\section{Contribution of School Meals to Nutrient INTAKE}

Lunchtime nutrient intake* on weekdays was calculated for children surveyed during school term. Children who took between one and four school meals had intakes which fell between those of children who had taken no school meals and five school meals. For clarity these are omitted from the tables.

Younger children who had eaten five school meals had a higher lunchtime intake of nearly all nutrients than those who had eaten no school meals (Table VI). For both sexes the differences in intake of

TABLE I

REPORTED TERM-TIME LUNCH SOURCE BY AGE-SEX GROUP

\begin{tabular}{|c|c|c|c|c|c|c|c|c|c|}
\hline \multirow{2}{*}{\multicolumn{4}{|c|}{$\begin{array}{c}\text { Term-time } \\
\text { Lunch } \\
\text { Source }\end{array}$}} & \multicolumn{3}{|c|}{ Age 8-11 } & \multicolumn{3}{|c|}{ Age 13-15 } \\
\hline & & & & Boys & Girls & Total & Boys & Girls & Total \\
\hline School & .. & .. & .. & $161(80 \cdot 1) \dagger$ & $155(79 \cdot 5)$ & $316(79 \cdot 8)$ & $148(78 \cdot 3)$ & $136(71 \cdot 2)$ & $284(74 \cdot 7)$ \\
\hline \multicolumn{3}{|c|}{ Home (prepared by mother) } & .. & $36(17 \cdot 9)$ & $34(17 \cdot 4)$ & $70(17 \cdot 7)$ & $26(13 \cdot 8)$ & $29(15 \cdot 2)$ & $55(14 \cdot 5)$ \\
\hline Other.. & . & .. & .. & $4(2 \cdot 0)$ & $6(3 \cdot 1)$ & $10(2 \cdot 5)$ & $15(7.9)$ & $26(13 \cdot 6)$ & $41(10 \cdot 8)$ \\
\hline Total & .. & . & .. & $201(100 \cdot 0)$ & $195(100 \cdot 0)$ & $396(100 \cdot 0)$ & $189 *(100 \cdot 0)$ & $191(100 \cdot 0)$ & $380(100 \cdot 0)$ \\
\hline
\end{tabular}

2 'not known' omitted

†Percentages are given in parentheses

*Lunchtime intake comprised all food and drink recorded as eaten between 12.0 noon and $2.0 \mathrm{pm}$ 
TABLE $11 \mathrm{I}$

REPORTED TERM-TIME LUNCH SOURCE BY NUMBER OF SIBLINGS

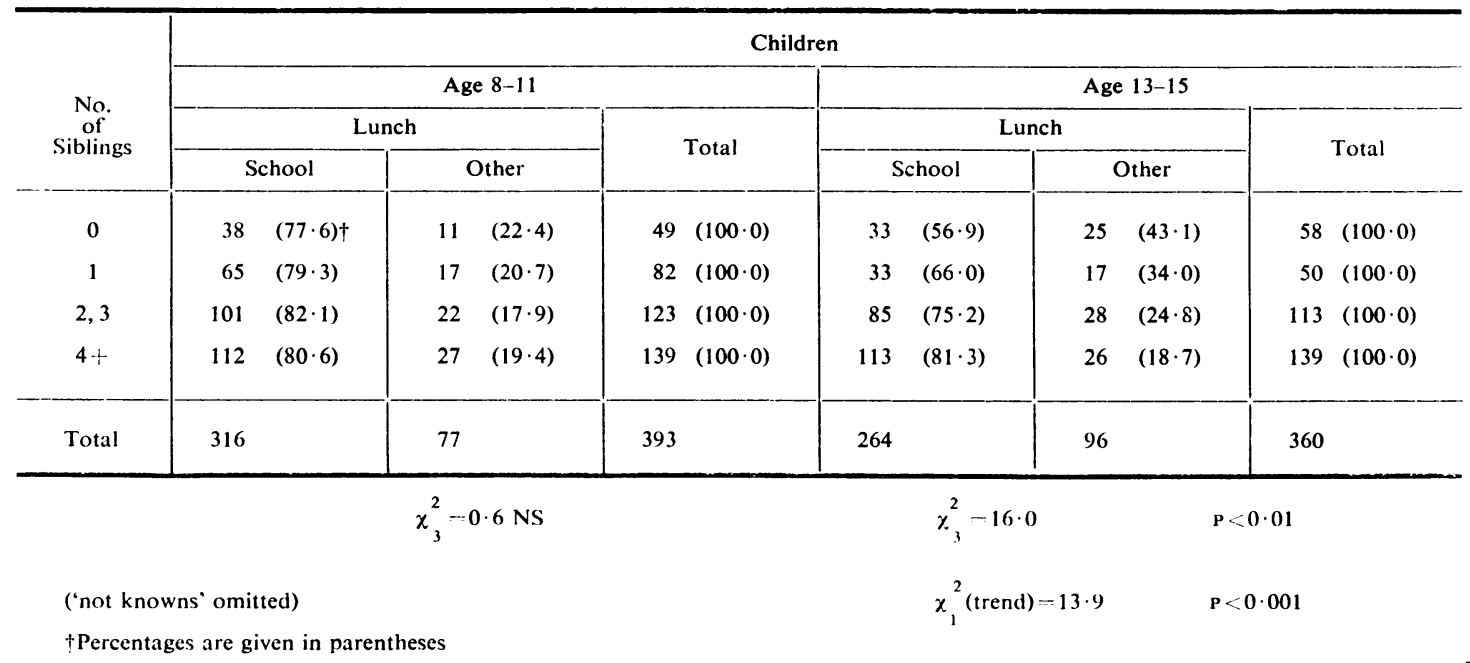

TABLE IV

REPORTED TERM-TIME LUNCH SOURCE BY MOTHER'S WORK STATUS

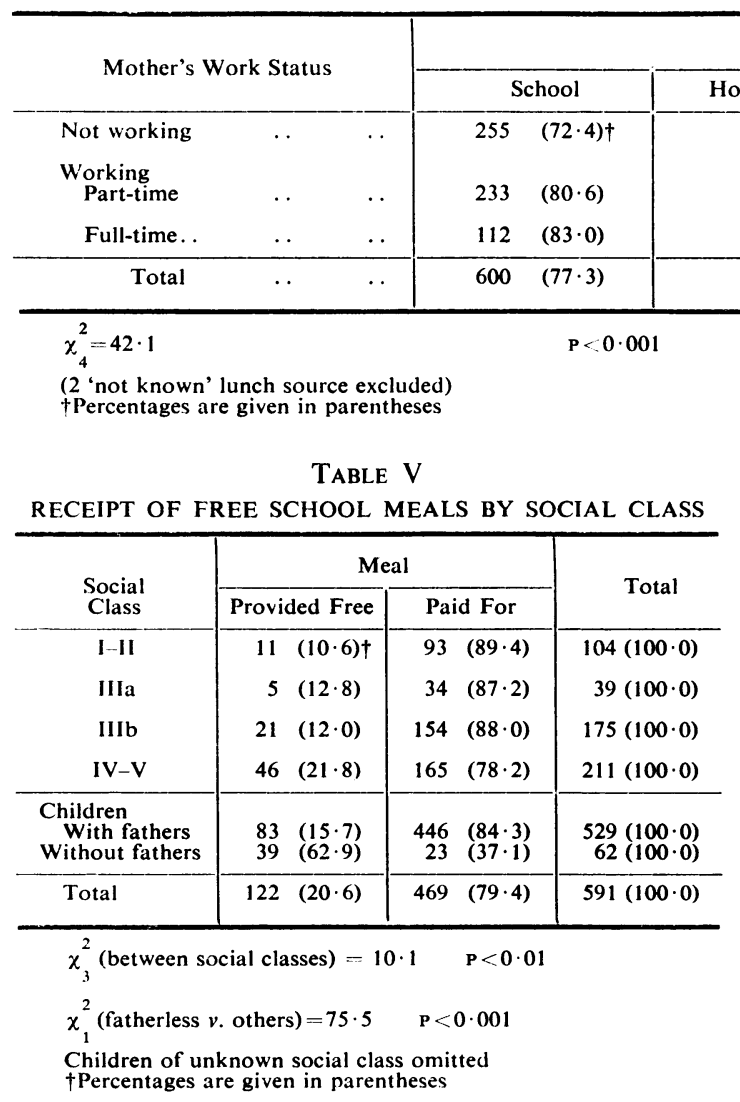

calcium were highly significantly greater for children having five school meals, as were intakes of animal protein and total protein for the boys only.

Older girls taking five school meals had similar lunchtime nutrient intake as those not taking school meals. In contrast older boys who took five school meals had significantly greater intake of energy and all nutrients except vitamin $A$ than those taking no school meals.

To compare the quality of lunchtime food intake and eliminate the influence of the differences in energy intake between groups, intake of nutrients /1000 kcal was calculated for food and drink consumed at weekday lunchtimes.

Younger boys taking five school meals had a significantly higher intake/1000 kcal of animal protein, calcium, and vitamin $\mathrm{D}$, and a significantly lower intake/1000 kcal of nicotinic acid than those 
TABLE VI

INTAKE OF NUTRIENTS AT LUNCHTIME-COMPARISON BETWEEN CHILDREN TAKING SCHOOL MEALS EVERY DAY (5 DAYS) AND THOSE TAKING NONE DURING ONE SCHOOL WEEK (TERM-TIME RECORDS ONLY)

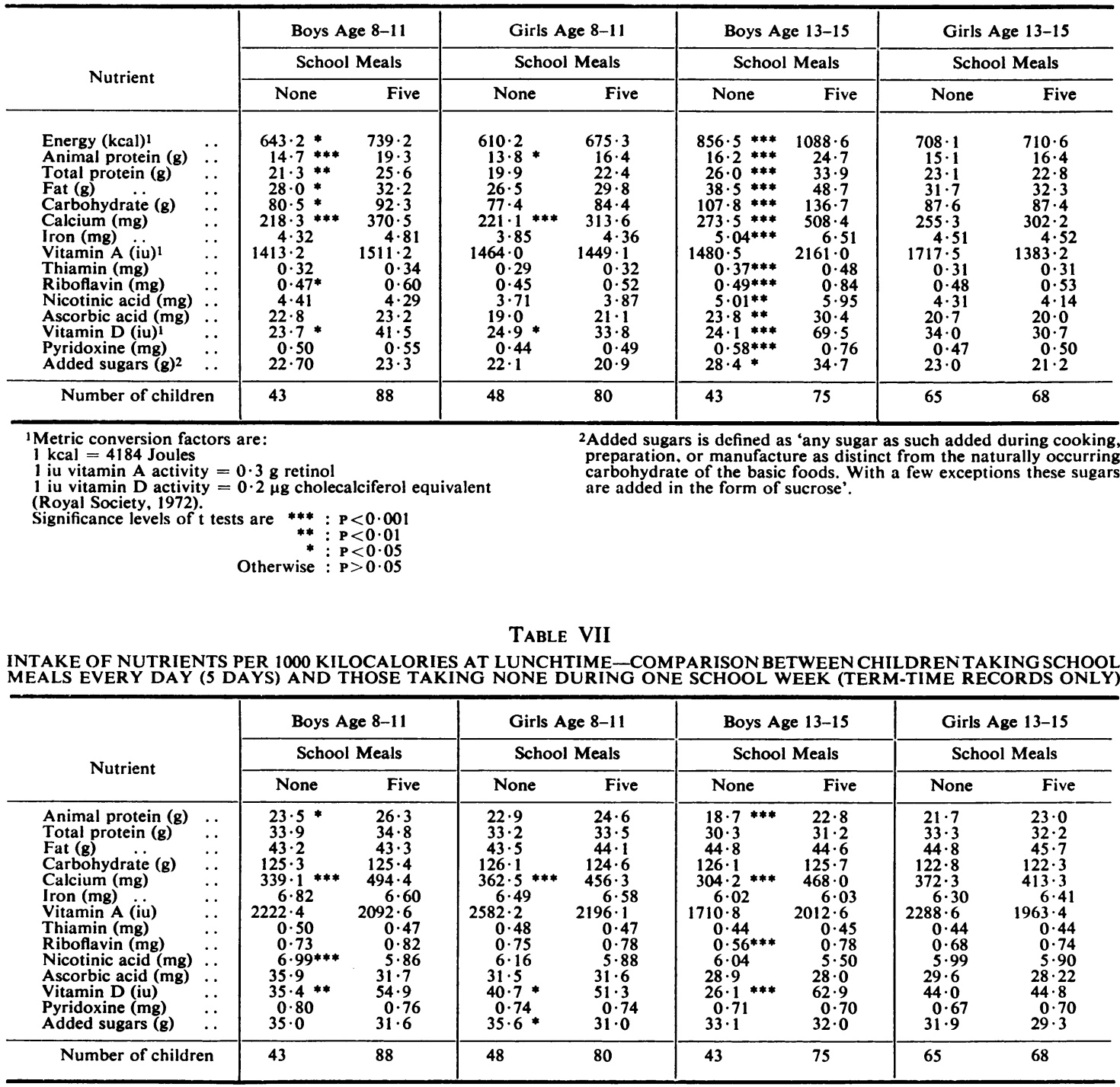

taking no school meals (Table VII). Among the younger girls those taking five school meals had a significantly higher intake $/ 1000 \mathrm{kcal}$ of calcium and vitamin $D$, but lower intake/1000 kcal of added sugars. Older boys taking five school meals had highly significantly greater intakes $/ 1000 \mathrm{kcal}$ of animal protein, calcium, riboflavin, and vitamin $D$ compared with those not taking school meals.

Similar differences in total daily intake were found between children who ate five school meals and those who ate no school meals as intake outside the lunchtime period did not differ greatly between the groups.

\section{Lunchtime Intake as a Proportion of Weekday NUTRIENT INTAKE \\ The proportion of weekday nutrient intake obtained at lunchtime was compared for children with term-time diet records taking no school meals and those taking five school meals.}



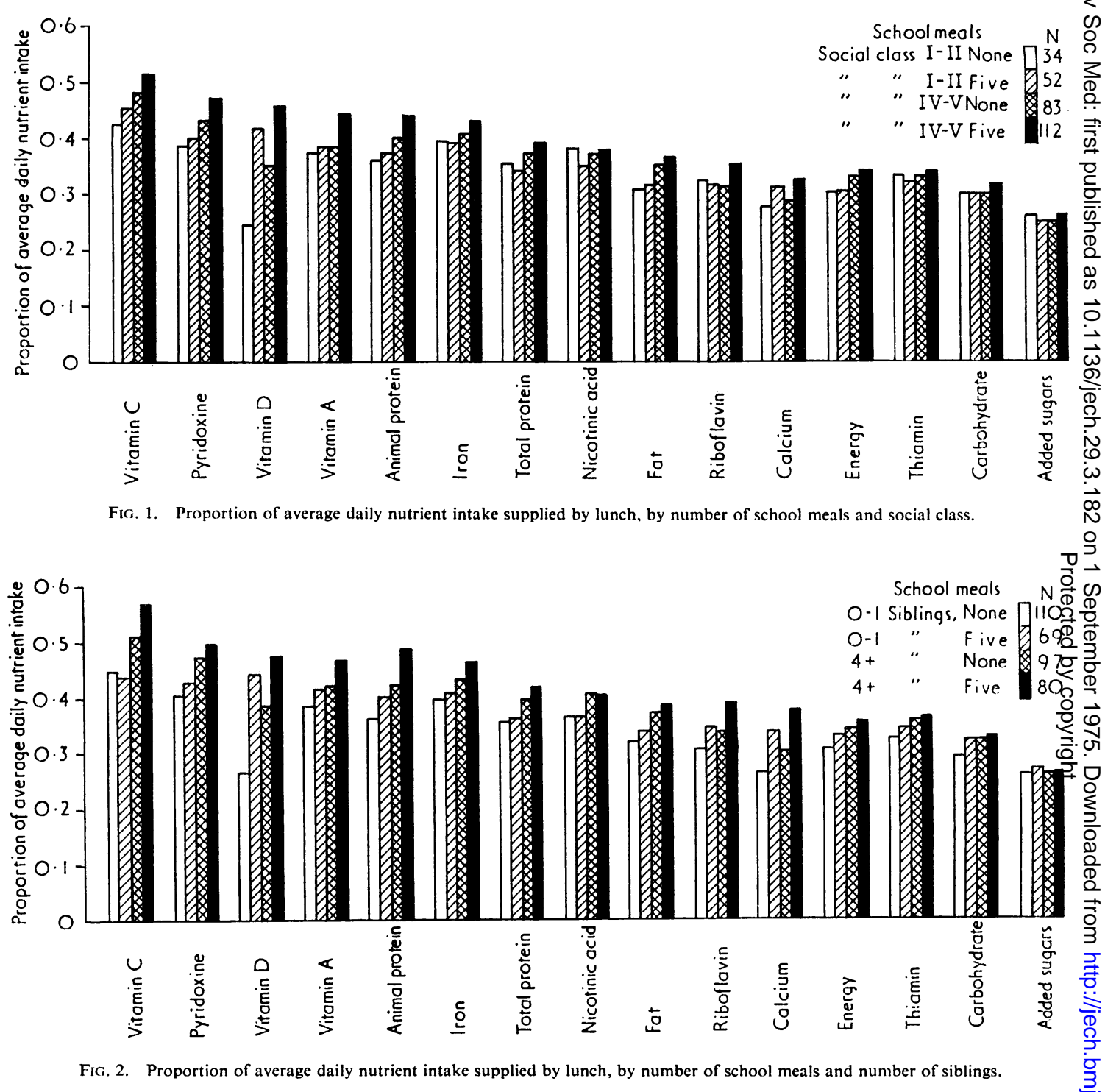

Fig. 1 compares children from social classes I and II with those from social classes IV and V. The proportion of weekday intake from lunch of children from social class III fell between that of the other two groups and is omitted from the figure.

Children from social classes IV and V taking five school meals obtained a higher proportion of their weekday intake at lunchtime than the other groups. They obtained a very much higher proportion of their weekday intake of most nutrients from lunch than other children of the same social classes who took no school meals. In contrast children of social classes I and II showed no consistent pattern of differences between those who took 은 five school meals and those who took no school meals.

Fatherless children who took five school meals obtained a higher proportion of their day's nutrient intake from lunch than those who did not take $\Omega$ school meals. Children receiving school meals free $N$ also obtained a slightly higher proportion of their $N$ weekday intake from lunch compared with children who paid.

Fig. 2 presents similar data for different family $\frac{O}{\Phi}$ size groups. 
Children with four or more siblings obtained a higher proportion of their weekday intake from lunch. Within this group those taking five school meals derived a consistently higher proportion of their weekday intake from lunch. In general the differences within the group with no siblings were much smaller. Nutrients for which there were greatest differences were amongst those nutrients for which there were large differences between the social class groups.

\section{Nutritional Status}

The relationship between anthropometric measurements, assessed nutritional status, and school meals consumption was explored using multiple covariance analysis. (Covariates included were age, sex, social class, and number of siblings. Height was added as an additional covariate in the analysis of weight.) No significant differences in height, weight adjusted for height, skinfold thickness, or clinically assessed nutritional status were found between groups taking school meals and other types of term-time lunch.

\section{Nutritional Standard of the School Meal}

The most recent standard for the school meals is set out in the Department of Education circular 3/66 (Department of Education and Science, 1966). On average the meal should contain $29 \mathrm{~g}$ total protein (including approximately $18.5 \mathrm{~g}$ animal protein), $880 \mathrm{kcal}$ energy and $32 \mathrm{~g}$ fat. These average amounts apply to 12-year-old children, lower amounts are assumed for younger and higher for older children (Department of Education and Science, 1965). In practice 'the variations in the size of portions served to children of different age and sex will automatically regulate the protein and caloric value of the meals served' (Department of Education and Science, 1966).

Mean nutrient intake was calculated for all school meals consumed by children in the study (mean age 12.5 years approximately) and compared with the standard (applicable to 12-year-old children). There is no recommended standard for sugar content of school meals but circular 3/66 suggested amounts of food to be used in the preparation of 2000 school meals. The mean sugar content of a school meal prepared using these suggested amounts was calculated using sugar content factors supplied by the Department of Health and Social Security (Department of Health and Social Security, 1974).

The mean energy value $(801 \mathrm{kcal})$ and total protein content $(26 \mathrm{~g})$ of school meals consumed in the study were somewhat lower than the standard although animal protein content was about the same as the standard $(19 \mathrm{~g})$. The mean fat content $(36 \mathrm{~g})$ was rather higher. The mean sugar content of school meals in the study ( $25 \mathrm{~g})$ was about one-third higher than that calculated from suggested amounts of sugar-containing foods (19 $\mathrm{g})$.

\section{Discussion}

Kent secondary schoolchildren had a higher uptake of school meals $(80 \%)$ than London secondary schoolchildren (41\%) (Richardson and Lawson, 1972). More Kent secondary schoolchildren $(16 \%)$ had lunch at home than in the London survey (4\%). This may be related to differences in the distance travelled to school and to differences in the proportion of mothers in employment.

School meals uptake was higher among children from lower social classes, larger families, and fatherless families. It is likely that this was due in part to government provision of free school meals to those in need. Most of the fatherless children took school meals and a high proportion of these were receiving them free. Expediency also appeared to be a factor as more children whose mothers worked took school meals.

With the exception of girls aged 13-15 years school meals provided children with a higher intake of energy and nutrients, and were richer in calcium and vitamin $D$ than alternative types of lunch. However the lack of differences in height, weight, skinfold thickness, and clinically assessed nutritional status must be considered in the interpretation of these variations in food intake.

Study children from lower social classes and larger families had lower daily nutrient intake/1000 kcal than other children (Cook et al., 1973) and were more likely to have less than the recommended daily intake of calcium and riboflavin (Cook et al., 1975). Fatherless children had a lower daily intake of energy and nutrients compared with children with fathers.

Children from these groups who took school meals, when compared with other children, derived a higher proportion of their weekday intake of both energy and nutrients from lunch. This applied particularly to animal protein, pyridoxine, vitamins $A$ and $D$, and iron which are nutrients important for growth. Conversely the rest of the weekday diet of these children was relatively poorer in these nutrients and contained a higher proportion of carbohydrate and added sugars than that of other children. This suggests that families without a father, those in lower social classes, and with large 
numbers of children relied to a greater extent than others on the intake of nutrients important for growth from school meals. This reliance may or may not depend on a conscious decision. The present study took place before recent large increases in the cost of protein-rich foods and such families may now rely even more on the food intake from school meals. This will need to be considered in future nutritional recommendations for school meals. The recommendation from circular 290 , that 'the school dinner must take into account the possibility of deficiencies in a child's home diet' (Ministry of Education, 1955) is still relevant. Consequently any reduction in the protein content of school meals would be undesirable.

Less expensive sources of protein might be used to hold down the cost of providing the required amount of protein in the school meal. Milk, cheese, and poultry cost less per gram of animal protein than carcase meat, eggs, and fish (Smith, 1974). It is also possible that relatively more vegetable protein could be included in school meals.

In two recent studies school meals did not reach the standard set by the Department of Education and Science (Bender, Magee, and Nash, 1972; Richardson and Lawson, 1972). A study of child health and nutrition in Sweden found school lunches provided lower energy intake and were higher in fat content than the recommended Swedish dietary allowances for school lunches (Samuelson, 1971). Richardson, on the other hand, found the fat content of school meals eaten by London secondary schoolchildren to be below the standard.

The standard nutrient content of school meals and suggested amounts apply to meals as served and not as eaten; mean nutrient content of school meals in this study on the other hand represents food actually eaten. This makes it difficult to compare school meals actually eaten and the standard set by the Department of Education and Science. With this reservation school meals eaten in the present study met the standard. The energy intake was slightly lower than had been recommended and this may indicate that the standard was too high for the energy requirements of these children. Their mean daily energy intake was lower than recommended by the Department of Health and Social Security (Cook et al., 1973). The part played by sugar in the development of childhood obesity and dental caries has been much debated. Bender et al., (1972) considered that in their survey the sugar content of school meals was too high. In the present study school meals provided children with about one-third more sugar than the suggested amounts per school meal. There was however no evidence from this study that children normally taking school meals were more likely than others to be assessed as obese at clinical examination.

This work has been supported in part by a grant from the Department of Health and Social Security. We wish $\underset{+}{\stackrel{D}{+}}$ to thank the district nurses, midwives, education service $O$ staff, and health visitors of the former Kent County Council for work on the field survey; Mrs A. Melton and Mrs B. Winstanley for supervising the field work; $\mathrm{Dr} \overparen{\nabla}$ W. T. C. Berry, Mrs M. Disselduff, and Dr S. J. Darke $\varrho$

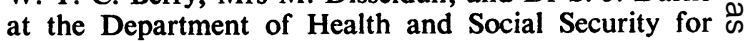
advice and guidance; Dr S. J. Darke for carrying out a $\overrightarrow{0}$ proportion of medical examinations and Mrs J. Swan and Marti Parker for work on the analysis. The data $\vec{\omega}$ were analysed using the University of London CDC 6600 and 7600 . In particular we wish to thank the families and children who worked so hard on the diet recording

Requests for reprints: Dr Judith Cook, Department $\omega$ of Community Medicine, St Thomas's Hospital Medical $\vec{\infty}$ School, London SE1 7EH.

\section{REFERENCES}

Bender, A. E., Magee, P., and Nash, A. H. (1972 Survey of school meals. Brit. med. J., 2, 383.

Cook, J., Altman, D. G., Jacoby, A., Holland, W. W and ElliotT, A. (1975). The contribution made by school milk to the nutrition of primary schoolchildre Brit.J. Nutr., 34, 91.

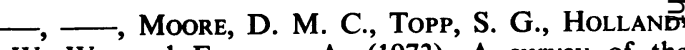
W. W., and ElliotT, A. (1973). A survey of the nutritional status of schoolchildren: relation between nutrient intake and socio-economic factors. Brit. J. prev. soc. Med., 27, 91.

Department of Education and Science (1965). The Nutritional Standard of the School Dinner. HMSO, London.

Department of Education AND Science (1966). The Nutritional Standard of School Dinners. Circular 3/66. HMSO, London.

Department of Health and Social Security (1974). Personal communication.

Ministry of EDUCATION (1955). The Nutritional Standard of School Dinners. Circular 290. HMSO, London.

Richardson, D. P. and Lawson, M. (1972). Nutritional value of midday meals of senior schoolchildren. Brit. med. J., 4, 697.

ROYAL SOCIETY (1972). Metric Units, Conversion Factors and Nomenclature in Nutritional and Food Sciences. $\%$ Report of the Subcommittee on Metrication of the $N$ British National Committee for Nutritional Sciences 1972. Royal Society, London.

Samuelson, G. (1971). An epidemiological study of child health and nutrition in a northern Swedish county. Acta paediat. scand., Suppl. 214. 
SMITH, B. J. (1974). Personal communication: calculation TopP, S. G., CooK, J., and ElliotT, A. (1972). Measurebased on data from reports of the National Food Survey published by the Ministry of Agriculture, Fisheries and Food, and the Retail Prices Survey ment of nutritional intake among schoolchildren: published by the Department of Prices. aspects of methodology. Brit. J. prev. soc. Med., 26, 106. 